\title{
WORKSHOP PELAKSANAAN PENELITIAN TINDAKAN KELAS PADA MUSYAWARAH GURU MATA PELAJARAN (MGMP) MATEMATIKA KOTA SOLOK, SUMATERA BARAT
}

\author{
Sefna Rismen, Hafizah Delyana, Audra Paramitha M, Melisa dan Mulia Suryani \\ Program Studi Pendidikan Matematika \\ Sekolah Tinggi Keguruan dan Ilmu Pendidikan PGRI Sumatera Barat, Indonesia \\ E-mail: hafizahdelyana@gmail.com
}

\begin{abstract}
Classroom Action Research is one effort that can be done by professional teachers in improving the quality of learning. The purpose of community service is to improve teachers' understanding in understanding PTK and can carry out PTK. This activity is intended for math teachers who are members of MGMP in High School. The form of service activities carried out in this activity is in the form of material delivery, practice of making proposals and consulting tasks. The workshop activity was attended by 30 high school mathematics teachers in Solok City. The results of this activity manifested 30 class Action research proposals.
\end{abstract}

Keywords: PTK, MGMP, Mathematics Teachers.

\begin{abstract}
Abstrak
Penelitian Tindakan Kelas (PTK) merupakan salah satu upaya yang dapat dilakukan guru profesional dalam peningkatan kualitas pembelajaran. Tujuan pengabdian pada masyarakat ini adalah untuk menigkatkan pemahaman guru dalam memahami PTK serta dapat melaksanakan PTK. Kegiatan ini diperuntukan bagi guru-guru matematika yang tergabung dalam MGMP SMA Kota Solok. Bentuk kegiatan pengabdian yang dilaksanakan dalam kegiatan ini adalah berupa penyampaian materi, praktik pembuatan proposal dan konsultasi tugas. Kegiatan workshop diikuti sebanyak 30 orang guru matematika tingkat SMA di Kota Solok. Hasil kegiatan ini terwujudnya 30 proposal penelitian Tindakan kelas.
\end{abstract}

Kata kunci: PTK, MGMP, Guru Matematika.

\section{PENDAHULUAN}

Profesi guru sebagai agen pembelajaran mensyaratkan 4 (empat) kompetensi, yaitu kompetensi pedagogik, kepribadian, sosial, dan profesional ${ }^{1}$. Kompetensi profesional merupakan kemampuan penguasaan materi pelajaran secara luas dan mendalam. Salah satu upaya yang dapat dilakukan guru profesional untuk meningkatkan kualitas pembelajaran adalah melalui penelitian tindakan kelas (PTK). Guru wajib dinilai kinerjanya dan melaksanakan kegiatan Pengembangan Kepfofesian Berkelanjutan (PKB). Salah satu kegiatan PKB yang dapat dilakukan oleh guru adalah melaksanakan penelitian ${ }^{2}$.

Untuk mewujudkan hal tersebut guru harus mempunyai kemampuan meneliti, khususnya Penelitian Tindakan Kelas (PTK).Namun kenyataannya banyak guru yang belum mampu melakukan penelitian, penelitian masih merupakan kegiatan yang dirasakan sangat sulit bagi guru.

Perkembangan PTK semakin meluas dibelahan dunia ini, termasuk di Indonesia mulai dikenal pada akhir dekade 80-an. Di Indonesia, PTK mulai digerakkan pada waktu upaya-upaya perbaikan mutu pendidikan di mulai dengan renovasi di tingkat pendidikan guru sekolah dasar, kemudian meluas ke kalangan guru-guru sekolah

\footnotetext{
${ }^{1}$ Undang-Undang Republik Indonesia Nomor 14 Tahun 2005 tentang Guru dan Dosen

${ }^{2}$ Permenegpan \& RB Nomor 16 tahun 2009, tentang Jabatan fungsional Guru dan Angka Kreditnya
} 
menengah $^{3}$. Saat ini, PTK banyak dilakukan para tenaga pengajar sebagai upaya pemecahan masalah dan peningkatan mutu pendidikan dan pembelajaran. Jenis penelitian ini bermanfaat bagi tenaga pengajar dalam rangka meningkatkan mutu proses dan hasil pembelajaran. PTK merupakan pencermatan terhadap kegiatan belajar berupa sebuah tindakan, yang sengaja dimunculkan dan terjadi dalam sebuah kelas secara bersama. Dalam PTK dikembangkan berbagai model pembelajaran yang dipakai sebagai salah satu variabel untuk meningkatkan kualitas pembelajaran ${ }^{4}$. Melalui PTK permasalahan pendidikan dan pembelajaran dapat dikaji, ditingkatkan, dan dituntaskan, sehingga proses pendidikan dan pembelajaran berlangsung secara inovatif serta memperoleh hasil belajar yang lebih baik.

Guru adalah pendidik professional dengan tugas utama mendidik, mengajar, membimbing, mengarahkan, menilai, dan mengevaluasi peserta didik pada pendidikan dasar dan menengah yang diharapkan mampu mengerahkan dan mendayagunakan factor-faktor yang berhubungan dengan pendidikan sehingga teripta proses belajar mengajar yang bermutu. Tanpa mengabaikan peran factor-faktor lain, guru dapat dianggap sebagai factor tunggal yang paling menentukan terhadap peningkatan mutu pendidikan. Jadi guru merupakan SDM yang harus menguasai ilmu pengetahuan dan teknologi yang mampu mendidik siswanya. Penelitian tindakan adalah suatu bentuk penelitian refleksi diri yang dilakukan oleh para partisipan dalam situasi-situasi sosial (termasuk pendidikan) untuk memperbaiki praktik yang dilakukan sendiri ${ }^{5}$. Untuk mengembangkan profesionalisme guru, sangat terkait dengan kegiatan Penelitian Tindakan Kelas (PTK). PTK pada hakekatnya merupakan kegiatan ilmiah yang dapat digunakan sebagai bahan refleksi untuk kegiatan pembelajaran di kelas secara ilmiah dan dapat dipertanggungjawabkan. Karena PTK merupakan penelitian yang dilakukan guru dikelasnya sendiri berdasarkan permasalahan yang dialaminya.

PTK merupakan penelitian tindakan yang dilakukan oleh guru sekaligus sebagai peneliti di kelasnya atau bersama-sama dengan orang lain (kolaborasi) dengan jalan merancang, melaksanakan, dan merefleksikan tindakan secara kolaboratif dan partisipatif yang bertujuan untuk memperbaiki atau meningkatkan kualitas proses pembelajaran di kelasnya melalui suatu tindakan tertentu dalam suatu siklus ${ }^{6}$.

Sasaran daerah pengabdian yang hendak dituju adalah Sekolah Menengah Atas (SMA) sederajat se Kota Solok. Dari data yang ada, guru-guru di SMA tersebut sebagian besar adalah memiliki kepangkatan III dan VIa, dimana sebagian besar dari mereka belum memperoleh kuota sertifikasi guru. Artinya sebagian besar dari mereka membutuhkan dukungan bukti fisik dalam mengikuti uji sertifikasi guru. Kondisi ini menggambarkan bahwa sebagian besar guru-guru SMA tersebut sangat bersemangat

\footnotetext{
${ }^{3}$ Rusydi, Ananda. 2015. Penelitian Tindakan Kelas. Bandung: Citapustaka Media, hlm.32.

${ }^{4}$ Arikunto, Suharsimi. 2006. Peneilitian Tindakan Kelas. Jakarta: Bina Aksara, hlm. 21

${ }^{5}$ Kemmis, S. and McTaggart, R. 1988. The Action Researh Reader. Victoria, Deakin University Press, hlm.43

${ }^{6}$ Kunandar. 2008. Langkah Mudah Penelitian Tindakan Kelas Sebagai Pengembangan Profesi Guru. Jakarta : Raja Grafindo Persada, hlm.22.
} 
dan berminat untuk mengembangkan potensi diri. Hal ini makin mendorong guru-guru untuk meningkatkan dan mengembangkan dan meningkatkan kompetensi mengajarnya.

Selama ini guru sebagai mitra lebih terfokus untuk mengajar dan mengejar target pencapaian materi pelajaran, tanpa diimbangi dengan kualitas pembelajaran di kelas. Padahal selain pencapaian materi, proses belajar yang ideal bagi siswa juga harus diperhatikan. Mitra sering mengalami kesulitan dalam mengajar. Banyak ditemukan berbagai persoalan di kelas, seperti pembelajaran kurang menarik, siswa kurang antusias, cara mengajar guru yang monoton, siswa ramai atau bermain sendiri, mengantuk, tidak semangat dan cenderung bersikap ke arah negatif, proses pembelajaran kurang interaktif, sehingga hasil belajar tidak mencapai target ketuntasan. Penggunaan media sebagai sarana dalam pembelajaran pun masih minim kreatifitas. Terbatasnya media peraga yang tersedia di sekolah, menjadi alasan dan kendala bagi guru untuk menyajikan pembelajaran yang inovatif.

Salah satu keinginan para guru adalah mengembangkan kompetensinya yang diharapkan berimplikasi pada peningkatan kualitas siswanya. Tuntutan yang paling esensial dalam meningkatkan mutu pendidikan adalah dengan peningkatan perbaikan proses pembelajaran. Terpenuhinya tuntunan ini diharapkan dapat diperoleh melalui workshop Penelitian Tindakan Kelas (PTK) untuk memperoleh informasi bagaimana mengajar dan belajar dengan baik. Selama ini pemahaman penelitian tentang memperbaiki kinerja guru agar hasil belajar siswa menjadi meningkat, hanya diperoleh melalui buku-buku tentang bagaimana upaya meningkatkan strategi pembelajaran di kelas tanpa mencoba mengetahui dan mengatasi hambatan-hambatan yang langsung mereka alami di kelas. Sebagai salah satu faktor penghambat dalam memecahkan masalah yang dihadapi guru di kelas, karena kurangnya pemahaman guru tentang penelitian tindakan kelas yang dapat dilakukan guru. Berdasarkan uraian di atas, progam pengabdian masyarakat untuk peningkatan pemahaman guru tentang PTK perlu dilakukan dengan tujuan untuk menginkatkan kompetensi guru melakukan penelitian sebagai upaya perbaikan mutu pembelajaran.

\section{METODE PELAKSANAAN}

Kegiatan prgram pengabdian pada masyarakat yang dilaksanakan adalah kegiatan pelatihan yang ditujukan kepada guru-guru matematika SMA yang tergabung dalam MGMP Matematika Kota Solok. Metode pelaksanaan pada program Pengabdian Pada Masyarakat adalah dengan mengadakan workshop PTK dan pebimbingan dalam penyusunan proposal PTK. Proses pelaksanaan workshop tersebut antara lain:

1. Pembuatan pedoman penulisan Penelitian Tindakan Kelas (PTK), yaitu Sebelum workshop diadakan terlebih dahulu tim membuat pedoman penulisan PTK. Pedoman ini merupakan petunjuk bagi guru-guru dalam membuat dan menyusun proposal PTK.

2. Pelaksanaan Workshop Penyuluhan PTK, yaitu Workshop dilaksanakan di SMA Negeri 3 Solok. Sekolah mitra menyediakan ruangan untuk pelaksanaan workshop. 
Materi workshop diberikan oleh dosen program studi pendidikan matematika STKIP PGRI Sumatera Barat.

3. Pembimbingan Pembuatan Proposal PTK, yaitu Setelah diberikan penyuluhan dan pengetahuan tentang Penelitian Tindakan Kelas (PTK), setiap guru diharapkan membuat proposal dan melaksanakan penelitian tindakan kelas di kelas masingmasing. Dalam proses pembuatan proposal PTK, guru-guru tersebut dibimbing oleh tim dosen. Sehingga guru-guru memiliki proposal penelitian tindakan kelas (PTK) masing-masing.

Evaluasi kegiatan dilakukan sepanjang pelaksana pengabdian yang dilakukan. Evaluasi dlakukan melalui wawancara dan penilaian terhadap proposal yang dibuat oleh guru-guru pada saat workshop MGMP Matematika.

\section{HASIL DAN PEMBAHASAN}

Pelaksanaan P2M ini dilakukan di SMAN 3 Solok Sumatera Barat. Jumlah peserta yang hadir pada saat kegiatan pembekalan materi tentang pelaksanaan penelitian tindakan kelas adalah sebanyak 30 orang. Agenda kegiatan pengabdian di MGMP Matematika Kota Solok Sumatera Barat dilakukan pemaparan materi dengan nara sumber adalah tim pengabdi yang berjumlah 5 (lima) orang. Penyampaian materi dari tim pengabdi, antara lain: materi PTK (prinsip, prosedur, dan implementasi) dan materi penulisan laporan PTK. Penyampaian materi kemudian dilanjutkan dengan sesi tanya jawab mengenai berbagai kendala yang dihadapi guru dalam PTK termasuk dalam penulisan laporannya. Kegiatan pengabdian kemudian diikuti dengan praktik berupa penyusunan judul PTK, latar belakang masalah, rumusan masalah, tujuan, dan bentuk tindakan yang akan dilakukan. Pada kegiatan pembekalan ini peserta sangat antusias mengikuti penyajian materi penelitian tindakan kelas yang diberikan, hal ini terlihat dari aktivitas guru yang bertanya tentang pelaksanaan penelitian dan pengertian siklus serta analisis data. Kemudian guru juga masih mengalami kebingungan dalam hal memilih model pembelajaran dan mengembangkan perangkat pembelajaran serta membuat instrumen penelitian. Kesulitan yang paling mendasar dialami oleh guru-guru matematika adalah menulis proposal. Hal ini disebabkan oleh mereka tidak terbiasa menulis. Oleh karena itu dilakukan pembimbing oleh tim pegabdian.
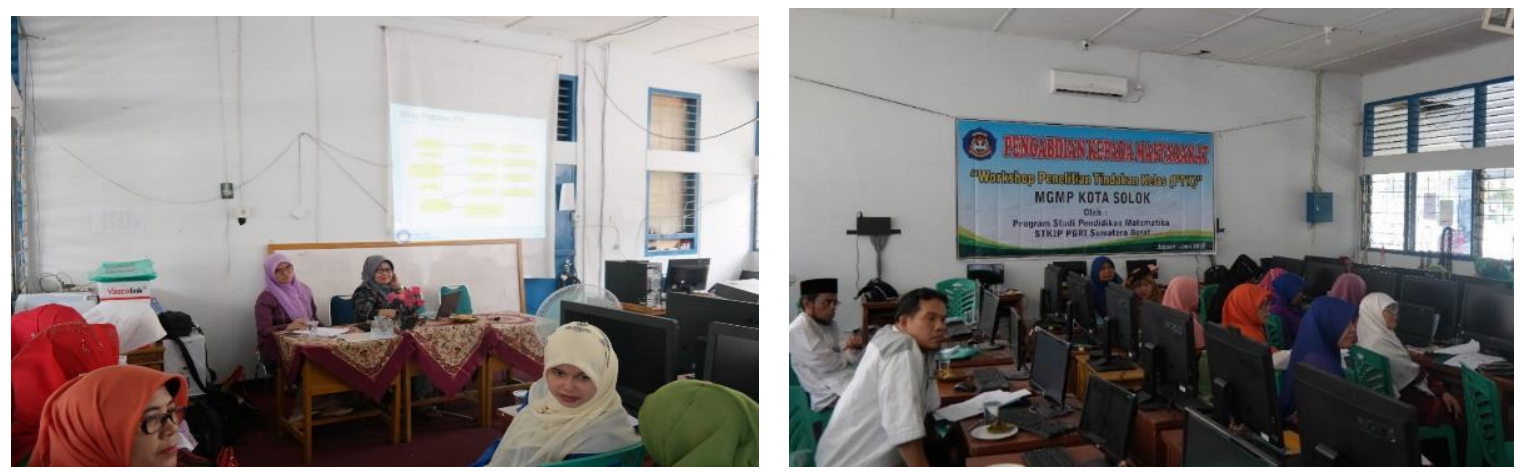

Gambar. Pelaksanaan Workshop di SMAN 3 Solok, Sumatera Barat 
Kegiatan pengabdian dilanjutkan dengan pemberian tugas individu pada para guru geografi SMA untuk membuat proposal PTK atau menulis laporan PTK dalam kurun waktu 6 bulan. Tugas individu bagi guru dikumpulkan secara kolektif melalui MGMP dan diberikan kepada tim pengabdi untuk mendapatkan masukan dalam rangka perbaikan. Pendampingan dilakukan oleh tim pengabdi dengan harapan lahir proposal penelitian yag layak digunakan. Hasil pembimbingan proposal yang diberikan oleh tim pengabdian masyarakat melahirkan 30 buah proposal PTK. Hasil penilaian yang dilakukan oleh tim pembimbing secara umum proposal yang dibuat sudah cukup bagus, namun dalam penulisan latar belakang masih belum logis dan rasional, kurang tepatnya pemilihan solusi yang dipilih guru dalam meyelesaikan permasalahan. Hasil wawancara yang dilakukan dengan beberapa orang guru diperoleh informasi bahwa guru-guru kesulitan dalam merangkai kata-kata untuk memulai penulisan proposal dan penulisan laporan penelitian.

\section{SIMPULAN}

Beberapa hal yang dapat disimpulkan dari hasil kegiatan pengabdian kepada mayarakat ini adalah:

1. Penelitian tindakan kelas merupakan suatu langkah nyata yang dilakukan oleh guru dalam memperbaiki kualitas pembelajaran yang dilaksanakannya. Hal ini didasari pada permasalahan yang dihadapi oleh guru saangat beragam dalam kegiatan belajar mengajar. Permasalahan harus diidentifikasi dan diformulasi untuk dicarikan upaya pemecahan dalam wadah penelitian tindakan kelas;

2. Pengetahuan dan pemahaman guru tentang pentingnya penelitian dalam pembelajaran matematika meningkat;

3. Jumlah guru yang berpartisipasi pada workshop sebanyak 30 orang;

4. Masing-masing guru sudah mampu mengidentifikasi permasalahan untuk pelaksanaan PTK;

5. Terciptanya 30 proposal penelitian PTK .

\section{SARAN}

Beberapa hal yang dapat disarankan dari kegiatan Pengabdian kepada masyarakat $(\mathrm{P} 2 \mathrm{M})$ ini yaitu antara lain:

1. Mengingat pentingnya penelitian dalam pembelajaran matematika, maka kegiatan pengabidan masyrakat ini dirasa perlu diperluas ke sekolah-sekolah lain di Provinsi Sumatera Barat agar menjangkau lebih banyak guru;

2. Guru-guru matematika hendaknya meningkatkan kualitas tulisannya dengan meningkatkan frekuensi latihan menulis. Dengan cara itu, kualitas tulisan dapat ditingkatkan. Selain, itu, guru-guru hendaknya banyak membaca referensi termasuk hasil- hasil penelitian yang dilakukan orang lain agar dapat menghasilkan ide-ide inovatif;

3. Bagi tim pengabdian masyarakat perlu melakukan evaluasi dari realisasi proosal yang sudah dibuat. 


\section{UCAPAN TERIMA KASIH}

Tim pengabdian masyarakat prodi pendidikan matematika berterimakasih kepada Program Studi Pendidikan Matematika, MGMP Matematika Kota Solok dan UP3M STKIP PGRI Sumatera Barat yang telah memberikan dukungan terlaksananya pengabdian ini, Pengabdian ini dilaksanakan berdasarkan dana mandiri.

\section{DAFTAR PUSTAKA}

Arikunto, Suharsimi. 2006. Peneilitian Tindakan Kelas. Jakarta: Bina Aksara. Kemmis, S. and McTaggart, R. 1988. The Action Researh Reader. Victoria, Deakin University Press.

Kunandar. 2008. Langkah Mudah Penelitian Tindakan Kelas Sebagai Pengembangan Profesi Guru. Jakarta : Raja Grafindo Persada.

Rusydi, Ananda. 2015. Penelitian Tindakan Kelas. Bandung: Citapustaka Media Undang-Undang Republik Indonesia No. 14 Tahun 2005 tentang Guru dan Dosen

Permenegpan \& RB Nomor 16 tahun 2009, tentang Jabatan fungsional Guru dan Angka Kreditnya 